\title{
Comparison of Marketing Strategies Between Emerging and Legacy Companies
}

\author{
Hongyu $\mathrm{Wu}$
}

\author{
College of Hospitality, Retail and Sport Management, University of South Carolina \\ Columbia, SC, 29201, the United States \\ Corresponding author.Email: hongyuw@email.sc.edu
}

\begin{abstract}
In this era of rapidly changing information, different companies' marketing strategies have varying degrees of impact on the company's future development. In this research, the author discusses the different marketing strategies between emerging companies and traditional companies in the fields of automobile manufacturing, hotel, and information technology through comparison. The research shows that after comparing the case studies of different industries, these strategies will correspond to the second, third, and fourth industries. The correct transformation of the company is more conducive to the company's long-term development. Studying its market position and market trends is particularly important for the development of enterprises.
\end{abstract}

Keywords: Marketing strategies, emerging companies, legacy companies, comparison, and comparative research

\section{INTRODUCTION}

In this examination, some monetary pointers are inspected and investigated to assess the critical impacts of promoting correspondence on chose organizations' budgetary circumstances. The effects depend on existing speculations of the function of fiscal pointers. This article calls attention the association between the chosen organizations' promoting apparatuses and budgetary markers. This study compares the marketing strategies and company development plans of emerging and legacy companies in different industries with its financial reports and stock values to explore the focus of today's company marketing. This article mainly refers to case studies conducted by other colleagues to discuss these companies' marketing strategies and get the empirical data in the company's earnings report to get theoretical support, compare the current recruiting strategies methods and discuss whether marketing strategies impact development. Finally, the author reaches the strategy prospects (market cap) and discusses whether the marketing strategy will affect the results. The following three different industry's comparison between emerging business and Well-established business will be shown. And finally we recap on all findings and discuss what these findings mean in the broad context.

\section{THE COMPARISON OF TESLA AND MERCEDES-BENZ}

\subsection{Car Manufacturing}

Tesla and Mercedes-Benz are famous brands in the automobile industry. Those two brands stand for two different eras of the car industry, which is the main reason for comparing those two companies. Tesla is a young company, which was established in 2003. Also, Tesla is a "Green" company by specialized in manufacturing environmentally friendly materials, electric vehicles, solar products, and integrated renewable energy solutions for households and businesses. It is committed to accelerating the world's transition to sustainable energy. High performance, sustainable transportation, and exclusive service are Tesla's value for the public.

Moreover, Tesla is one of the most significant electric vehicles and clean energy companies in America. After 11 years of development on the market, Tesla has become the world's bestselling plug-in and battery electric passenger car company in 2019. Tesla's car sales in the U.S. had risen $280 \%$ from 2017 to 2018, while global sales had risen $138 \%[2]$. 
Mercedes-Benz is a historical automobile company, which was founded in 1926 until 94 years. Meanwhile, Mercedes-Benz is a premium car marque in Germany specializing in the production of luxury and high-performance cars or commercial vehicles. It has created a lot of automotive technologies' invention we can see today, for example, crumple zone (1959), airbag (1980), and PRE-SAFE $®$ braking (2002). Moreover, the Mercedes-Benz company is devoted to corporate social responsibility, improving the lives of underserved and marginalized groups that hustle to bringing value and vitality to communities.

According to Tesla Marketing Plan, Tesla and Mercedes-Benz have a similar target population, and both selling cars ranging from $\$ 30 \mathrm{k}$ to $\$ 250 \mathrm{k}$. They are original target population upper and middle class, mostly wealthy and successful business executives or entrepreneurs, as their vision shifts to expanding more customers, the eco-friendly Gen Y. They are looking for the first luxury and high-performance cars in the mid-1920s and middle-class office workers in the early 1940s. Young professionals who are looking for an entry-level luxury car are the pinpointing target population. However, the vast difference between market cap - \$400B (Tesla) vs. \$50B (Mercedes) indicates that the market has a different expectation on earning ability in the future[1].

\subsection{Marketing Strategy}

According to Tesla's target market, print media is their direct marketing approach. This is because print media is more cost-effective and efficient than an alternative form of marking. They are active in showing up in well-known magazines to advertise marketing information to consumers such as Car and Driver, Wired, BusinessWeek, and Forbes magazine. This is based on Tesla's primary target market values and lifestyle. The use of "cars and drivers" is designed to specifically target car enthusiasts in Tesla's target market and make Tesla's strong word-of-mouth advertising cause a sensation in the automotive community. The choice of Wired magazine is because Tesla's target market is a group of innovators. They are well-informed high-tech consumers.

Due to increasing competition in the luxury car industry, Tesla has switched the marketing strategy to the digital platform. Generated information to the public is more lifestyle and it frequently shows up themselves on social media, such as Facebook and Twitter. Social media platforms can be highly interactive with the target audience and have communication with potential audiences.

Similar to Tesla, Mercedes Benz had switched their original marketing strategies from luxury to more lifestyle-oriented. The main reason is the increasing competition in a luxury car and the customer's attitude variation. Mercedes Benz is demonstrating a more fun-loving and energetic side of Mercedes Benz. They also changed their slogan from "Engineered Like No Other Car in the World" to "sacrifice nothing." It can clearly state the market shift procedures.

\subsection{Findings}

It is not hard to find that the strategies from those two companies are similar, which leads us to consider whether a customer-oriented approach always possible. There is no doubt that many companies choose not to compete in an extremely competitive environment, and they will find a new position to avoid the loss, even like Mercedes Benz. It has steadily developed a routine, while an appropriate transformation still benefits long-term development.

\section{THE COMPARISON BETWEEN AIRBNB AND MARRIOTT}

\subsection{Hospitality Industry}

The hospitality industry covers worldwide, and the traditional hospitality form like Marriott represents the hotel industry even services industry. However, from 2008, a new hospitality version emerged. Airbnb, also known as a home-sharing business, gives more options to people about choosing where to stay during a vacation or business trip. The comparison between Marriott and Airbnb would enlighten the new idea of marketing strategies.

Airbnb comes from the words Air Bed and Breakfast. It was an idea to put air mattress into bed and breakfast. But now Airbnb, Inc. becomes a rental online marketplace company. And Marriott, Inc., established in 1927, is a legacy multinational diversified hospitality company that runs hotels and related lodging facilities. Both Airbnb and Marriott are now operating globally, with millions of users are consuming them. According to the data online, at the end of 2019, Marriott has 1.29 million units worldwide, and Airbnb has four times more than Marriott with 4.92 million units. The difference is significant. However, it is mainly because of the different business models. Airbnb is adopting the aggregator business model like Uber and OYO; The sharing economy is being everywhere in our life. Airbnb is a carrier to connect renters and landlords, helping travelers looking for short-term or long-term rentals with reasonable prices, and renters will be charged a service fee.

Marriott is known as a hospitality company that franchises a wide range of hotels and related lodging facilities. The luxury services and hotel make them a good reputation. For example, the Ritz-Carlton, as one of Marriott's brand categories, has legendary service for 
the guests, enriching the guests with thoughtful experiences while living. According to the Wall Street Journal, start from April 2019, Marriott start challenging the home-sharing business with Airbnb. Home \& Villas by Marriott International is the same mode as home-sharing like Airbnb, but with upscale properties. Marriott offers 2000 "premium and luxury homes" in more than 200 cities [3]. The market capitals between Airbnb and Marriott are $\$ 50$ billion compares to $\$ 30$ billion.

Difference between market cap - $\$ 50 \mathrm{~B}$ (Airbnb) vs. \$30B (Marriott) is not hard to find that Airbnb has surpassed Marriott from the market assessment. Marriott is probably searching for changing the business direction to home-sharing and challenge Airbnb [4].

\subsection{Marketing Strategies}

As mentioned before, Airbnb is not like the traditional hospitality industry. They are investing in registering properties on the list and recommended to the traveler. And the target is people who wish to find a nice place to live at affordable prices. And this strategy appeals to abundant people's eyes, which helps Airbnb's business develop rapidly since it had emerged. Within over ten years of development, Airbnb can be seen as the leader in the home-sharing market.

Marriott, a legacy brand of the hospitality industry, on the other hand, aims at luxury experiences for the customer. The target markets are high-class consumptions. While Airbnb has made a massive success in the home-sharing market, its market capitalization had surpassed Marriott. Marriott also enters the home-sharing business; Marriott's good advantage is their reputations for gathering people's attention quickly. However, the number of properties may be the biggest challenge for Marriott because Airbnb has four times more units than Marriott. Marriott has a long way to go.

\subsection{Findings}

From the comparison between Marriott and Airbnb, there is no doubt that the mass market directs the marketing strategies. There are massive market sharing and competition. And nowadays, a sort of shift for a company to meet customer's demands may have an unexpected outcome.

\section{COMPARISON BETWEEN MICROSOFT AND IBM}

Microsoft is a multinational computer technology company established in 1975 by Bill Gates and Paul Allen. And International Business Machines Corporation (IBM) was founded in 1911 in the information technology industry. Those two companies represent the emerging and legacy companies in the IT industry. In 1980, Microsoft company had formed a partnership with IBM to bundle Microsoft's operating system with IBM computers. Thus, it would be interesting to see an emerging company and legacy company cooperating while competing in marketing strategies.

Both companies are mainly focusing on Business to Business (B2B) mode and investing heavily in cloud computing; this is probably because of the developing trend, the cloud computing system is the future. As of November 2020, Microsoft's market cap has reached $\$ 1.6$ trillion, making them the world's third most valuable company. While IBM's market cap is $\$ 104.12$ billion, the data can show the decline of value [5]. The author here analyzes why the two companies have such a big difference in market value under a good cooperative relationship.

\subsection{Marketing Strategies}

Microsoft aims to invest in marketing messages through various marketing communication channels in an integrated manner. Besides, Microsoft will focus on the trend of the market and adjust. Regarding the target customer, Microsoft is focusing on a specific group among the population.

IBM is mainly focused on global expansion and increased outsourcing. At the same time, they also eagers the highest profitability by taking advantage of cost efficiencies. This strategy is risky and competitive, while "outsource" its development to another country (like India) helps reduce a large amount of cost and increase the profit margin. Meanwhile, global expansion enables the company to have higher stability. However, the company has suffered from declining financial performance [6].

\subsection{Findings}

A flexible strategy is essential while competing for the market share. The key is to understand the market trend. IBM was failing on financial performance because of the innovation. The new breed of innovative software companies could make computers cheaper than IBM, and IBM still focuses on profit margin. Considering market position, it is all about product, price, promotion, and place. IBM should realize the importance of innovation during the competitive market.

\section{CONCLUSION}

An appropriate transformation for a company is beneficial to long-term development. The market is varied. Future is unpredictable. Thus, to survive in a competitive market, it is essential to research the current market position and understand the future market trend. It is necessary to make adjustments with the fluctuated market; Otherwise, it may easy for a company to suffer 
a financial decline like IBM. A sort of shift for a company to meet customer's demand may have an unexpected outcome.

\section{ACKNOWLEDGMENT}

I would like to acknowledge everyone who played a role in my academic accomplishments. First of all, my parents, who supported me with love and understanding. Without them, I could never have reached this current level of success. Secondly, my professor and the people around me, each of them has provided patient advice and guidance throughout the research process. Thank you all for your unwavering support.

\section{REFERENCES}

[1] Writer, S., What Is Mercedes Benz's Target Market? 2020. https://www.reference.com/world-view/merc edes-benz-s-target-market-55582ab2ef50048e

[2] Mangram, M., The globalization of Tesla Motors: a strategic marketing plan analysis. Journal of Strategic Marketing, 2012. 20(4), pp.289-312.

[3] Karmin, C., Marriott To Take on Airbnb In Booming Home-Rental Market. WSJ. 2020. https:/www.wsj.com/articles/marriott-to-take-on-ai rbnb-in-booming-home-rental-market-1155653560 $0 ?$ mod $=$ djemalertNEWS

[4] Vakhariya, S., Airbnb: The emerging player of Sharing Economy in UAE. Case Studies in Business and Management, 2017, 4(2), p.144.

[5] Macrotrends. IBM Market Cap 2006-2020 online. 15, November 2020.

https://www.macrotrends.net/stocks/charts/IBM/ib $\mathrm{m} /$ market-cap.

[6] Panmore Institute. 2020. IBM'S Generic Strategy \& Strategic Choices, SWOT Analysis - Panmore Institute. 15 November 2020. 